\title{
Neurochemical identity of neurones expressing oestrogen and androgen receptors in sheep hypothalamus
}

\author{
A. E. Herbison \\ Laboratory of Neuroendocrinology, The Babraham Institute, Cambridge CB2 4AT, UK
}

\begin{abstract}
Gonadal steroids exert important feedback influences on hypothalamic neurones involved in regulating reproductive behaviour and pituitary hormone secretion. The recent development of antibodies specific for individual gonadal steroid receptors has been of great use in determining precisely which cells in the hypothalamus express androgen, oestrogen and progesterone receptors. In the sheep brain, both oestrogen and androgen receptor antibodies have been used successfully and the distribution of cells expressing both receptors has now been determined in ewes and rams, respectively. In addition, the predominantly nuclear localization of the steroid receptors has enabled double-labelling immunocytochemical procedures to determine the neurochemical phenotype of neurones expressing the steroid receptor. Work in the sheep hypothalamus shows that gonadotrophin-releasing hormone neurones do not possess oestrogen or androgen receptors. However, substantial numbers of cells containing oestrogen receptors in the preoptic area of ewes contain the inhibitory neurotransmitter gamma aminobutyric acid, while most oestrogen receptor-immunoreactive neurones in the ventromedial nucleus synthesize the inhibitory neuropeptide somatostatin. Androgen receptors have been detected in many of the ventromedial somatostatin neurones in rams. In contrast, the neurochemical phenotype of the great majority of oestrogen and androgen receptor-immunoreactive cells in the arcuate nucleus remains unknown. The identification of the neurotransmitters and neuropeptides synthesized by neurones possessing androgen and oestrogen receptors in different regions of the ovine hypothalamus provides a neuroanatomical basis for understanding the mechanisms by which gonadal steroids regulate reproductive function.
\end{abstract}

\section{Introduction}

The profile of LH secretion in ewes and rams depends upon the feedback actions of gonadal steroids throughout the year. In ewes, oestrogen acts in a primarily positive feedback manner during the breeding season to generate the LH surge, as well as oestrous behaviour, but changes to exert a negative feedback influence on $\mathrm{LH}$ secretion during anoestrus (Goodman, 1994). In rams, testosterone exerts negative feedback actions on LH pulse frequency which are greatest in efficacy during the non-breeding season (Pelletier and Ortavant. 1975; D'Occhio ef al, 1983). Although the pituitary gland is an important site of gonadal steroid action, studies examining the effects of restricted brain lesions and those involving measurement of portal GnRH concentrations have shown that the hypothalamus is an equally, if not more important, location of oestrogen and androgen action in the regulation of LH secretion (Caraty and Locatelli, 1988; Tilbrook et al., 1991 and see Goodman, 1994). Hence, to make 
further advances in our understanding of how steroids regulate LH release it has become essential that we define precisely which hypothalamic cell types are targeted by gonadal steroids to influence $\mathrm{GnRH}$ release into the portal circulation. As the effects of oestrogens and androgens depend upon season (Pelletier and Ortavant, 1975; Goodman, 1994) and the role of progesterone in regulating LH release is different in sheep compared with primates and rodents (Goodman, 1994), it may not be sufficient to simply extrapolate data on steroid-receptive cells from other species to sheep. In an effort to define the cells possessing oestrogen receptors in the sheep hypothalamus, we (Skinner et al., 1992; Herbison et al., 1993a) and others at Nouzilly (Batailler et al., 1992; Blache et al., 1994) and Cincinnati (Lehman et al., 1993; Lehman and Karsch, 1993) have used the H222 monoclonal antibody directed against the hormone-binding domain of the human oestrogen receptor to determine the cells immunoreactive for this receptor and elucidate the neurotransmitters or neuropeptides that they synthesize. This review summarizes work to date involving the characterization of cells expressing oestrogen receptors in the ovine hypothalamus and provides an overview of recent work using the PG-21 antibody directed against the amino-terminal domain of the human androgen receptor (Prins et al., 1991) to map and characterize cells possessing androgen receptors in the ram hypothalamus.

\section{Distribution of Oestrogen Receptor-Immunoreactive Cells in Ewes}

As in other mammals, most cells containing oestrogen receptors in the brain of the ewe are located in the preoptic area (POA), adjoining anterior hypothalamic area (AHA), ventrolateral septum, bed nucleus of the stria terminalis (BNST), ventromedial nucleus (VMN) and arcuate nucleus (ARN; Herbison et al., 1993a; Lehman et al., 1993; Blache ef al., 1994). Large numbers of oestrogen receptor-immunoreactive cells are found in the medial aspect of the POA adjacent to both the wall of the third ventricle and the organum vasculosum of the lamina terminalis, which itself possesses many oestrogen receptor cells. Although the density of oestrogen receptor-positive cells decreases markedly in the AHA, a distinct cluster of densely packed oestrogen receptor-immunoreactive cells is found in the dorsal AHA. It has been suggested that this cell group may be equivalent to the posterodorsal nucleus (PDN) of rats (Ju and Swanson, 1989; also called the striohypothalamic nucleus) and it appears to be continuous with the principal encapsulated nucleus of the BNST which shares a similar high density of oestrogen receptor-immunoreactive cells in rats and sheep (Herbison et al, 1993a). An oestrogen receptorcontaining, PDN-like structure has also been identified in the primate AHA (Herbison et al, in press). Between the POA-AHA and mediobasal hypothalamus, there are few oestrogen receptorimmunoreactive cells being present mostly in the immediate periventricular zone and above the optic chiasma. Similar to guinea-pigs, but not to rats or monkeys. (see Herbison et al., in press), oestrogen receptors have been detected in the supraoptic nucleus of ewes within its dorsomedial aspect. Only a very few oestrogen receptor-immunoreactive cells are found in the paraventricular nucleus. Within the mediobasal hypothalamus, oestrogen receptor-immunoreactive cells are clustered in the VMN and ARN. As in guinea-pigs (Blaustein and Turcotte, 1989) and primates (Herbison et al., in press), oestrogen receptor-immunoreactive cells in the VMN are located mainly in its ventrolateral division and extend in a broad band from beneath the fornix to the base of the brain where a small gap separates them from the oestrogen-receptor-containing cells of the ARN. In ewes, the highest density of oestrogen-receptorimmunoreactive cells is found in the ARN (Blache et al., 1994) and oestrogen receptor cells are distributed throughout the nucleus from the retrochiasmatic region to the level of the mammillary bodies. A few scattered oestrogen receptor-positive cells are present in the dorsomedial and posterior hypothalamic nuclei. A substantial number of oestrogen receptor-imunoreactive cells have been detected in the pars tuberalis (Skinner et al., 1992; Lehman and Karsch, 1993) and, as expected, in the pars distalis (Skinner et al., 1992) of the anterior pituitary gland. In addition, Lehman et al. (1993) reported oestrogen receptor-immunoreactive cells in the amygdala, hippocampus and periaqueductal grey of ovariectomized ewes.

The three studies that have described the distribution of oestrogen receptor-containing cells in ewes (Herbison et al., 1993a; Lehman et al., 1993; Blache et al., 1994) have all used the rat monoclonal $\mathrm{H} 222$ antibody (Greene et al., 1984) to define oestrogen receptors. Studies in rats with the $\mathrm{H} 2222$ antibody have 
shown clearly that circulating oestrogen concentrations must be low to enable optimal visualization of oestrogen receptor immunoreactivity (Cintra et al, 1986; Herbison and Theodosis, 1992a; Blaustein, 1993). Although oestrogen receptor synthesis is itself regulated by oestrogens (Simerly and Young, 1991), the dependence of $\mathrm{H} 222$ staining on the relative absence of oestrogen in rats is thought to result from direct competition between the $\mathrm{H} 222$ antibody and oestrogen for the hormone-binding site on the oestrogen receptor (Blaustein, 1993). On this basis, two of the distribution studies undertaken in ewes were carried out on ovariectomized animals (Herbison et al., 1993a; Lehman et al, 1993). However, the most recent investigation (Blache et al., 1994) used brain sections from both ovariectomized and steroid-treated, ovariectomized ewes and found no effect of oestrogen replacement on oestrogen receptor cell density in the POA, VMN or ARN. Overall, the distribution of oestrogen receptorimmunoreactive cells reported in this study was very similar to that given in the two previous reports in ovariectomized ewes. We also note (A. E. Herbison, unpublished) that the distribution and number of oestrogen receptor-immunoreactive cells are not markedly different in anoestrous and ovariectomized (see Herbison et al., 1993a) ewes. As oestrogen has been reported to increase nuclear oestrogen receptor concentrations in the POA and basal hypothalamus of ewes (Bittman and Blaustein, 1990), it is possible that oestrogen has little effect on the number of $\mathrm{H} 222$-stained cells detected as the competition between $\mathrm{H} 222$ and oestrogen is offset by the increased concentrations of oestrogen receptors. It is of note that nuclear oestrogen receptor immunoreactivity using the $\mathrm{H} 222$ antibody is similarly not altered greatly by oestrogen treatment in monkeys (Herbison et al, in press), guinea-pigs (Blaustein and Turcotte, 1989) and mice (Koch and Ehret, 1989). Why H222 staining should be so dependent on circulating oestrogens in rats but not ewes is not clear but may be related to species differences in the relative concentrations of oestrogen and oestrogen receptor within hypothalamic cells, or possibly conformational differences in the oestrogen receptor. However, Blache et al. (1994) did show that the administration of progesterone to ovariectomized ewes resulted in the detection of greater numbers of oestrogen-receptorimmunoreactive cells in the VMN. As the necessity for reduced oestrogen concentrations may not be of paramount importance when using the $\mathrm{H} 222$ antibody in ewes and the presence of progesterone is necessary to visualize maximal numbers of oestrogen receptors in the VMN, it may be more appropriate (and physiologically relevant) for future studies of oestrogen receptor-immunoreactive cells to be undertaken in intact ewes. A quantitative analysis of oestrogen receptor-immunoreactive cells in the hypothalamus of ewes in the breeding and non-breeding seasons might be helpful in determining whether there are differences in the number of oestrogen receptor-expressing neurones between the two seasons (Clarke et al., 1981; Glass et al., 1984; Bittman and Blaustein, 1990).

\section{Distribution of Androgen Receptor-Immunoreactive Cells in Rams}

Using the polyclonal rabbit PG-2I antibody, we carried out initial studies to determine the distribution of androgen-receptor-immunoreactive cells in the hypothalamus of rams during the non-breeding season (A. Herbison, D. Skinner, J. Robinson and I. King, unpublished). In general, the overall distribution of cells is very similar to that of oestrogen receptors in ewes, and the largest numbers of androgen receptor-immunoreactive cells are found in the POA, VMN and ARN. Many cells containing androgen receptors are found in the medial POA where they lie next to the wall of the third ventricle or in the organum vasculosurn of the lamina terminalis. Again, like cells expressing oestrogen receptors in ewes, fewer cells are seen in the AHA but a distinct cluster of androgen-receptor-containing cells is found in the PDN and the density and intensity of staining of these cells appear very similar to the androgen-receptor-immunoreactive cells detected in the principal encapsulated nucleus of the BNST. Cells immunoreactive for the androgen receptor are also located in other regions of the BNST and in the ventrolateral septum. Again, relatively few androgen-receptor-immunoreactive cells are found between the POA-AHA and mediobasal hypothalamus, although it is notable that androgen receptors are not detected in the supraoptic nucleus. A large population of androgen-receptor-containing cells is found in the VMN and most are located in the ventrolateral region similar to the oestrogen receptor-containing cells. However, a further group of androgen-receptor-immunoreactive cells is distributed more medially in the dorsomedial division of the VMN where oestrogen receptors are not found. Cells immunoreactive 
for the androgen receptor are detected throughout the ARN but at a much lower density compared with oestrogen-receptor-immunoreactive cells in ewes. Menard and Harlan (1993) using the PG-21 antibody in the rat brain, showed a very similar distribution of androgen-receptor-immunoreactive cells in the rat hypothalamus.

Although at present the comparison must be made between ewes and rams, it is apparent that there are both overlapping and dissimilar distributions of oestrogen-receptor- and androgen-receptorimmunoreactive cells in the sheep hypothalamus. The POA, lateral septum, PDN, principal encapsulated nucleus of the BNST and ventrolateral VMN appear to have very similar numbers and distributions of androgen receptor and oestrogen receptor cells. Other regions such as the supraoptic nucleus exhibit oestrogen receptors but not androgen receptors, whereas the dorsomedial VMN has androgen receptors but not oestrogen receptors and the ARN has markedly fewer androgen-receptor-containing cells compared with oestrogen-receptor-immunoreactive cells in ewes. The absence of androgen receptor immunoreactivity in intact ewes and only faint oestrogen receptor staining in intact rams (Herbison, unpublished) has prohibited us from determining whether the same cells in the overlapping regions express both oestrogen receptors and androgen receptors in intact animals. Geffroy-Roisné et al. (1993) demonstrated the presence of a cytosolic $50 \mathrm{kDa}$ oestrogen receptor in the ram hypothalamus and reported that there are no sex differences in the number of cytosolic oestrogen receptors detected in the POA and mediobasal hypothalamus (Glass et al., 1984). Our present studies using the $\mathrm{H} 222$ antibody in the intact ram indicate that the distribution of oestrogen-receptor-immunoreactive cells is approximately similar to that of its androgen-receptor-containing cells. However, the low intensity of oestrogen receptor immunoreactivity in intact rams suggests that oestrogen receptor protein concentrations in the cell nucleus may be lower in males than in females. The potential for aromatized androgens to compete with the $\mathrm{H} 222$ antibody for the oestrogen-receptor-hormone-binding domain makes investigation of castrated rams necessary to clarify this point.

\section{Absence of Oestrogen and Androgen Receptors in Sheep GnRH Neurones}

It is now apparent that GnRH neurones in a variety of species do not possess gonadal steroid receptors. In terms of androgen and oestrogen receptors, previous studies have reported that the GnRH neurones in female and male rats (Shivers et al., 1983; Herbison and Theodosis, 1992a), guinea-pigs (Watson et al, 1992) and female monkeys (Herbison et al, 1994) do not possess oestrogen receptor immunoreactivity or concentrate tritiated oestradiol. Studies with ovariectomized (Herbison et al., 1993a; Lehman and Karsch, 1993) and anoestrous (Herbison, unpublished; Fig. Ia) ewes have similarly demonstrated that $\mathrm{GnRH}$ neurones throughout the hypothalamus do not display oestrogen receptor immunoreactivity. With respect to androgen receptors, recent work has shown that the GnRH neurones of rats do not possess androgen receptors (Huang and Harlan, 1993) and our own studies (Herbison, unpublished; Fig. Ib) in intact rams also show an absence of androgen receptor immunoreactivity within GnRH neurones located throughout the hypothalamus. A further consistent observation from these doublelabelling studies in sheep, guinea-pigs and monkeys is that GnRH neurones are usually surrounded by oestrogen-receptor- and androgen-receptor-immunoreactive cells (Fig. Ia, b). It seems likely therefore that the genomic influences of oestrogen and androgen upon GnRH neurones are mediated by steroid-receptive interneurone populations.

\section{Neurochemical Identity of Oestrogen- and Androgen-Receptor-Expressing Cells in Sheep Hypothalamus}

\section{Preoptic and anterior hypothalamic areas}

The only neuronal cell population shown to express oestrogen receptors in the POA is the population that synthesizes the inhibitory amino acid, gamma amino butyric acid (GABA, Fig. Ic). Oestrogen-receptive neurones synthesizing GABA can be found throughout the POA and AHA and make up approximately $40 \%$ of the oestrogen-receptor-immunoreactive cells in the central region of the 


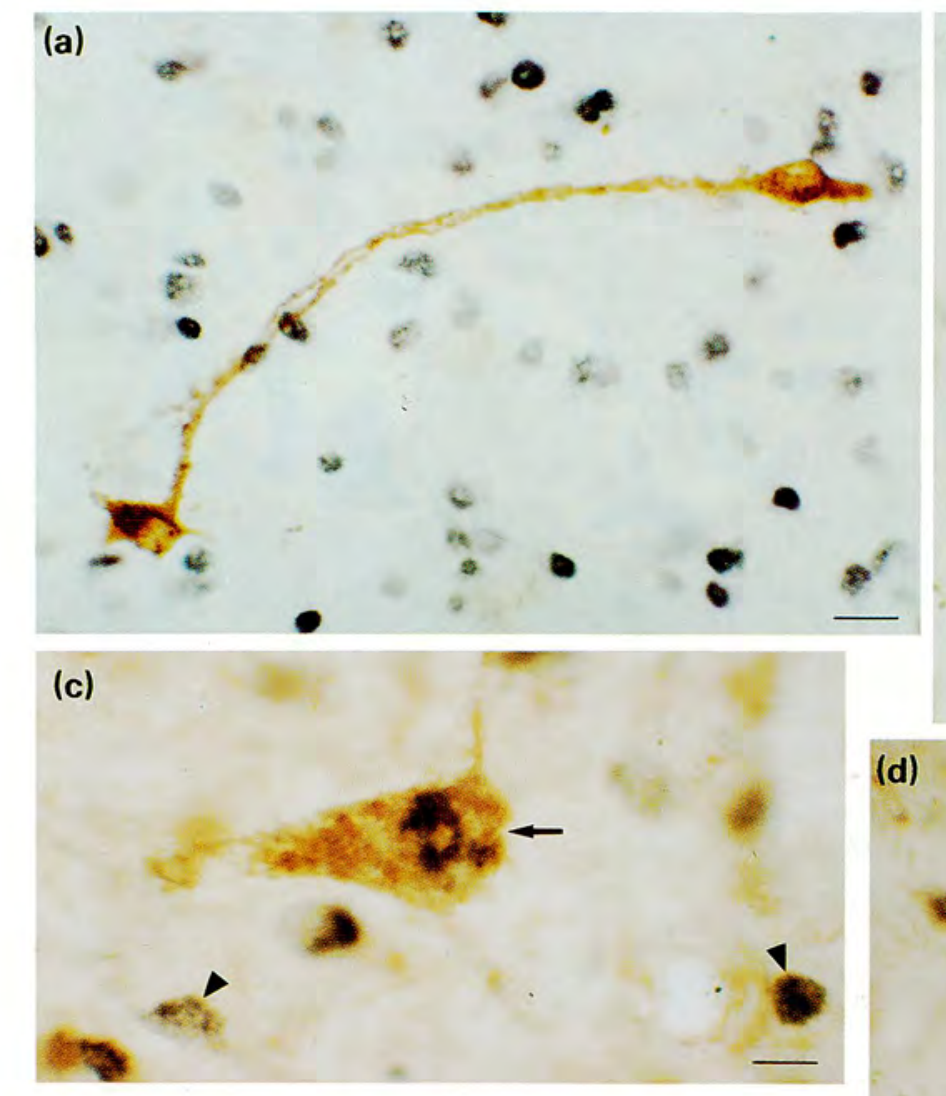

(b)
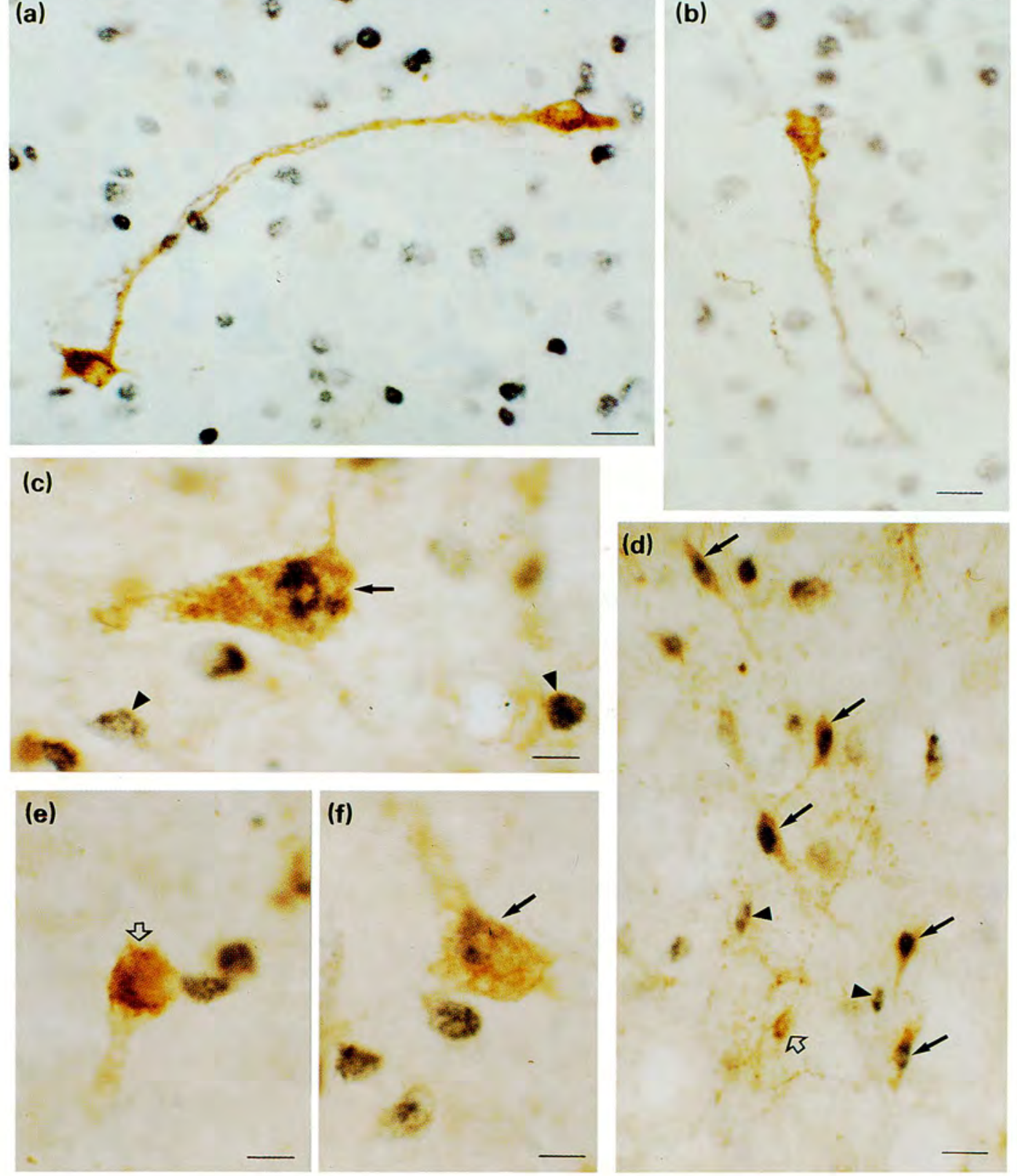

Fig. 1. High power views of sheep preoptic area (a, b, c, e), ventromedial nucleus (d) and bed nucleus of the stria terminalis ( $f$ ) following double-labelling immunocytochemistry for (a) oestrogen receptor and GnRH, (b) androgen receptor and $\mathrm{GnRH}$, (c) oestrogen receptor and glutamic acid decarboxylase (marker for GABA), (d) androgen receptor and somatostatin, and (e and f) oestrogen receptor and calcitonin gene-related peptide. Double-labelled cells with black nuclear staining (oestrogen or androgen receptor) and brown cytoplasmic staining (neuropeptide) are marked by solid arrows, some of the cells possessing only oestrogen or androgen receptor nuclear staining are indicated by arrowheads and other cells with only neuropeptide immunoreactivity are labelled with open arrows. Note that GnRH neurones do not possess oestrogen receptors or androgen receptors but are surrounded by cells possessing these receptors. In (d) a high abundance of androgen receptor and somatostatin co-expression is observed in the ventromedial nucleus. Only those double-labelled cells clearly in the plane of focus are marked with an arrow. (a) anoestrous ewe; (b and d) intact non-breeding season ram; (c, e, f) ovariectomized ewe. Scale bars represent $15 \mu \mathrm{m}(\mathrm{a}, \mathrm{b}), 5 \mu \mathrm{m}(\mathrm{c}, \mathrm{e}, \mathrm{f})$ and $25 \mu \mathrm{m}(\mathrm{d})$. 
Table 1. Neurotransmitters and neuropeptides synthesized by oestrogen receptor(ER)-immunoreactive cells of ewe hypothalamus

\begin{tabular}{|c|c|c|c|c|c|}
\hline $\begin{array}{l}\text { Neurotransmitters/ } \\
\text { neuropeptide }\end{array}$ & $\begin{array}{l}\text { Sheep } \\
\text { model }\end{array}$ & Location & $\begin{array}{c}\text { ER cells } \\
\text { containing } \\
\text { neurochemical } \\
\text { (\%) }\end{array}$ & $\begin{array}{c}\text { Identified } \\
\text { neurones } \\
\text { with ER } \\
(\%)\end{array}$ & Reference \\
\hline CGRP & $\begin{array}{l}\mathrm{OVX} \text { and } \\
\text { anoestrus }\end{array}$ & $\begin{array}{l}\text { Paraventricular nucleus } \\
\text { and preoptic area }\end{array}$ & 0 & 0 & Herbison, unpublished \\
\hline \multirow[t]{3}{*}{ Dopamine } & $\mathrm{OVX}+\mathrm{P}$ & A12 (arcuate nucleus) & $<10$ & $=$ & Batailler et al., 1992 \\
\hline & OVX & A12 (arcuate nucleus) & - & $3-5$ & Lehman and Karsch, 1993 \\
\hline & & $\mathrm{A} 11, \mathrm{~A} 13, \mathrm{~A} 14, \mathrm{~A} 15$ & 0 & 0 & Lehman and Karsch, 1993 \\
\hline$\beta$-Endorphin & ovx & Arcuate nucleus & - & $15-20$ & Lehman and Karsch, 1993 \\
\hline GABA & ovx & Preoptic area & 30 & 40 & Herbison et al., 1993 \\
\hline \multirow[t]{3}{*}{ GnRH } & ovx & Preoptic area & 0 & 0 & Herbison et al., 1993 \\
\hline & OVX & Hypothalamus & 0 & 0.1 & Lehman and Karsch, 1993 \\
\hline & Ánoestrus & Hypothalamus & 0. & 0 & Herbison, unpublished \\
\hline \multirow[t]{3}{*}{ SOM } & Anoestrus & Periventricular & 0 & 0 & Herbison, unpublished \\
\hline & & Ventromedial nucleus & $\sim 70$ & $\sim 35$ & Herbison, unpublished \\
\hline & & Arcuate nucleus & 0 & 0 & Herbison, unpublished \\
\hline
\end{tabular}

Summary of co-localization studies with regard to oestrogen-receptor-containing neurones in the hypothalamus of ewes. Note that results for the oestrogen receptor and somatostatin arise from just two anoestrous ewes and percentages are therefore given as approximations. Abbreviations: AI2-A15, the various dopaminergic cell groups; CGRP: calcitonin gene-related peptide; OVX: ovariectomized; $O V X+P$ : ovariectomized ewes treated with progesterone; SOM: somatostatin: GABA: gamma amino butyric acid.

POA and about $30 \%$ of the many neurones containing GABA located in this area (Table 1; Herbison et al., 1993a). Although studies have yet to be conducted to establish whether GABA neurones in the $P O A$ express androgen receptors, the density of GABA neurones and androgen-receptorimmunoreactive cells in this region make co-expression likely. The A14 group of dopaminergic neurones residing in the POA do not possess oestrogen receptors in ovariectomized ewes (Lehman and Karsh, 1993). The small number of parvocellular neurones containing calcitonin gene-related peptide (CGRP) found in the POA (Herbison et al., 1993b) are not immunoreactive for oestrogen receptors in either ovariectomized or anoestrous ewes (Fig. 1), or androgen receptors in intact rams (Herbison, unpublished). However, a few neurones staining lightly for CGRP located in the BNST have been detected to express oestrogen receptors (Fig. If).

\section{Periventricular region}

Although oestrogen-receptor-immunoreactive cells are readily detectable in this region outside of the paraventricular nucleus (PVN), double-labelling studies have failed to detect oestrogen receptors in any of the dopaminergic cells in this region (Lehman and Karsch, 1993). Neurones in the AI5 group of dopaminergic cells located medial to the optic tracts are similarly devoid of oestrogen receptor immunoreactivity (Lehman and Karsch, 1993). No oestrogen receptor or androgen receptor immunoreactivity has been detected in the magnocellular CGRP neurones of the ventral PVN (Herbison ef al. $1993 \mathrm{~b}$ ) or the somatostatin neurones located throughout the PVN (Herbison, unpublished).

\section{Ventromedial nucleus}

Preliminary work in anoestrous ewes has shown that, as in rats (Herbison, 1994), a large population of somatostatin-immunoreactive neurones are located in the ventrolateral VMN and over a third of these cells express oestrogen receptors in ewes and androgen receptors in rams (Herbison, unpublished). In 
ewes, about $70 \%$ of the neurones expressing oestrogen receptors in this region synthesize somatostatin compared with approximately $40 \%$ of androgen-receptor-immunoreactive cells in the ventrolateral VMN of rams (Fig. Id). The dorsomedial division of the VMN receives a dense somatostatin innervation and it seems likely that the androgen-receptor-immunoreactive cells in this region receive somatostatin inputs.

\section{Arcuate nucleus}

Batailler et al. (1992) and Lehman and Karsch (1993) have shown that a small subpopulation of the A12 dopaminergic neurones scattered throughout the ARN express oestrogen receptors. In the former study, these cells were estimated to account for less than $10 \%$ of all oestrogen-receptor-immunoreactive neurones in the ARN, while in the second report, 3-5\% of the dopaminergic neurones were shown to be immunoreactive for the oestrogen receptor. Preliminary investigations (Herbison, unpublished) have been unable to detect androgen receptors in A12 dopaminergic neurones of rams. More numerous in the ARN, however, are the $15-20 \%$ of $\beta$-endorphin-immunoreactive cells that possess oestrogen receptors (Lehman and Karsch, 1993). Although located throughout the ARN, neurones co-expressing $\beta$-endorphin and oestrogen receptors are clustered in particularly large numbers at the base of the third ventricle. The small population of somatostatin neurones located in the dorsomedial aspect of the ARN do not possess oestrogen receptors (Herbison, unpublished).

\section{Anterior pituitary}

Large numbers of gonadotrophs expressing oestrogen receptors are reported in the pars tuberalis (Skinner et al., 1992; Lehman and Karsch, 1993) and pars distalis (Skinner et al., 1992) of ewes and all oestrogen-receptor-immunoreactive cells in the anteroventral region of the pars tuberalis are gonadotrophs (Skinner et al. 1992). Faint androgen receptor imunoreactivity can be detected in the pars tuberalis of rams.

\section{Species Differences}

As the GnRH neurones of all mammals examined lack nuclear gonadal steroid receptors, there may be a common indirect mechanism of gonadal steroid input to these cells. Across species uniformity in specific steroid-receptive cells believed to interact with $\mathrm{GnRH}$ neurones might suggest an essential role for these cell types in, for example, the generation of the LH surge, while the identification of steroid-receptive populations peculiar to a single species might suggest a role for these cells in steroid-dependent functions unique to that species. At present, all four of the neurochemically identified neural populations containing oestrogen receptors in sheep have also been reported to express oestrogen receptors in the same regions of the rodent brain: the preoptic GABA neurones (Flugge et al., 1986). cells in the ventromedial nucleus containing somatostatin (Herbison, 1994) and the dopaminergic and $\beta$-endorphin neurones of the ARN (Sar, 1984; Morell et al., 1985; Jirikowski et al., 1986). Equally, the dopaminergic neurones of the POA-AHA and periventricular somatostatin cells do not express oestrogen receptors in either ovariectomized sheep or rats (Sar, 1984; Herbison and Theodosis, 1992a, 1993). In contrast, however, the preoptic CGRP neurones of sheep do not display oestrogen receptors (Fig. 2) or sex differences (Robinson and Herbison, unpublished) as they do in rats (Herbison and Theodosis, 1992b) and the presence of oestrogen receptors in neurones containing neurotensin, natriuretic peptide and galanin, as found in the rat preoptic area (Herbison and Theodosis, 1992a; Bloch et al, 1992; Watson et al, 1994), has not been reported in sheep. However, it was surprising to find that the A12 dopaminergic cells of female monkeys do not express oestrogen receptors (Herbison et al., 1994), suggesting a species difference in the steroid regulation and a precise role of this neuroendocrine cell population. Although present observations in the sheep are restricted to the identification of neural populations the detection of which does not require colchicine treatment, the above argument would indicate that the oestrogen receptive GABA, somatostatin and $\beta$-endorphin neurones (Fig. 2 ) in the 


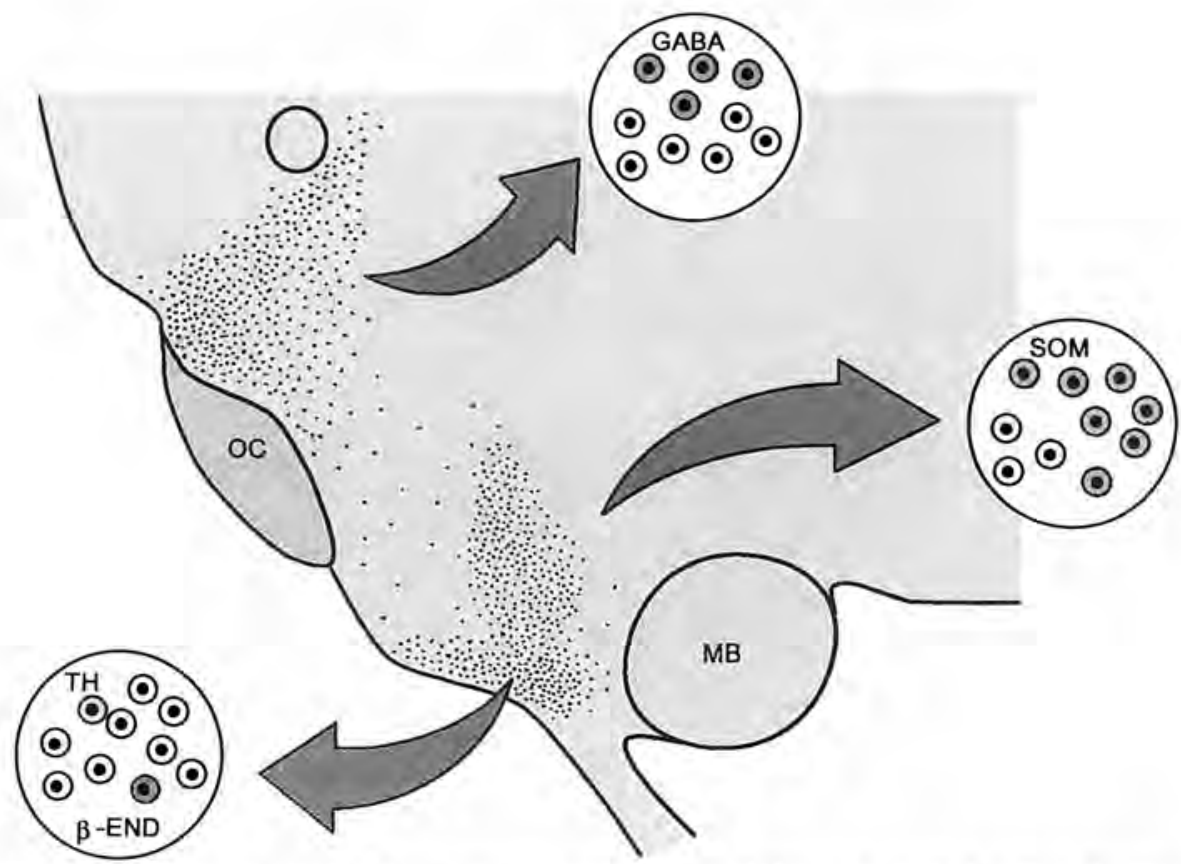

Fig. 2. Schematic drawing of sheep preoptic area and hypothalamus in sagittal section showing the three main populations of cells expressing oestrogen receptors in the preoptic area, ventromedial and arcuate nuclei. Circular insets show the relative percentage of oestrogen receptor-expressing cells (cells with black nuclei) synthesizing different neurotransmitters (shaded cells) in each region. $\beta$-END: $\beta$-endorphin; GABA: gamma aminobutyric acid; $M B$; mammillary bodies; OC: optic chiasma: SOM: somatostatin; TH: tyrosine hydroxylase (marker for dopamine).

POA, VMN and ARN, respectively, form part of a core group of gonadal-steroid-expressing neurones responsible for the regulation of elements of reproductive behaviour common to several species.

\section{How do Oestrogens and Androgens Influence GnRH Neurones?}

The identification of cells possessing oestrogen receptors and androgen receptors in the sheep hypothalamus is clearly far from complete; the neurotransmitters and neuropeptides synthesized by $60-100 \%$ of oestrogen-receptor-and androgen-receptor-containing cells in the POA is unknown, as is the identity of $80-90 \%$ of steroid-receptive neurones in the ARN. Furthermore, the precise relationship of the various populations of neurones expressing gonadal steroid receptors to the steroid-dependent control of different components of reproductive hormone secretion or behaviour are unknown. Nevertheless, the present information (Fig. 2), combined with neural monitoring and neuropharmacological studies in sheep provides a start in determining the way in which oestrogens and androgens are likely to orchestrate several neural populations to influence the activity of GnRH neurones.

In sheep, dopamine is perhaps the most investigated of the classical neurotransmitters with respect to a role in mediating gonadal steroid influences on $\mathrm{LH}$ secretion. Results from several laboratories (see Goodman, 1994) indicate that dopamine may be particularly important in mediating part of the negative feedback effects of oestrogen on LH during the non-breeding season in ewes. It has been proposed that the rostral hypothalamic A14 and A15 dopaminergic neurones (Thiery et al., 1988; Havern et al., 1994) can inhibit GnRH release presynaptically at the level of the median eminence (Kuljis and Advis, 1989) and that these neurones are activated by oestrogen during the non-breeding season but not at other times (Goodman, 1994). It is perplexing, therefore, to find that the A14 and A15 dopaminergic neurones 
do not express oestrogen receptor immunoreactivity in ovariectomized ewes (Lehman and Karsch, 1993). Such observations indicate that if the AI4 and A15 groups are to be involved in oestrogen negative feedback on LH secretion, oestrogen must influence these cells either indirectly, through yet another interneurone population, or in a non-genomic manner. Indirect evidence to support the latter contention comes from recent studies in rats in which oestradiol exerts rapid non-genomic actions on A10 dopaminergic neurones (Thompson and Moss, 1994). A further possibility for the A14 and A15 cells is that they may express immunocytochemically detectable oestrogen receptors only in anoestrous and not in ovariectomized or breeding season ewes when dopamine is not thought to have a role in regulating LH secretion (Goodman, I994). However, it would seem that this does not occur in GnRH neurones, as oestrogen receptors do not appear in $\mathrm{GnRH}$ neurones during anoestrus (Fig. 1a). It is of equal interest that dopamine is not implicated in the negative feedback actions of testosterone on $\mathrm{LH}$ in rams during the non-breeding season (Tilbrook and Clarke, 1992), suggesting that there are sex differences in oestrogen receptor or androgen receptor localization or expression at this time. The role of the oestrogen-receptive ARN dopamine neurones in regulating GnRH neurones is unknown, but it is possible that they may contribute to the presynaptic innervation of the nearby GnRH terminals (Kuljis and Advis, 1989). Our preliminary evidence suggests that there is a sex difference in steroid receptor expression by ARN dopaminergic neurones, as they do not appear to express androgen or oestrogen receptors in rams (Herbison, unpublished) but express oestrogen receptors in ewes (Batailler et al., 1992; Lehman and Karsch, 1993).

Preoptic GABA neurones are thought to have an important influence on the activity of neighbouring GnRH neurones in ewes (Robinson et al,, 1991; Robinson and Kendrick, 1992; Scott and Clarke, $1993 \mathrm{a}, \mathrm{b})$. However, precisely what role they play in the gonadal steroid regulation of LH secretion in sheep is not clear. During the breeding season, preoptic infusion studies indicate that GABA actions through the $\mathrm{GABA}_{\mathrm{A}}$ receptor are essential for the normal pulsatile release of $\mathrm{LH}$ (Scott and Clarke, 1993a) and that a fall in extracellular GABA concentrations in the vicinity of the GnRH neurones occurs before the oestrogen-induced LH surge (Robinson et al, 1991). Whether this decrease in GABA is brought about by oestrogen is unknown, but work in the rat POA suggests that this is unlikely as mRNA expression of glutamic acid decarboxylase, the synthetic enzyme for GABA, is not dependent on circulating oestrogen concentrations but falls before the LH surge (Herbison et al., 1992). At present it seems more probable that preoptic GABA neurones in ewes are targeted by progesterone during the breeding season to help bring about its negative feedback actions on $\mathrm{LH}$ secretion (Robinson and Kendrick, 1992). During the non-breeding season, however, recent work has indicated that $\mathrm{GABA}_{\mathrm{A}}$ receptors located in the POA may mediate part of the inhibitory effects of oestrogen on LH secretion. Bicuculline, the $\mathrm{GABA}_{\mathrm{A}}$ receptor antagonist, exerts similar inhibitory effects on $\mathrm{LH}$ secretion in the breeding season and in ovariectomized, anestrous ewes, but stimulates $\mathrm{LH}$ release in ovariectomized ewes the LH secretion of which has been inhibited by oestrogen during the non-breeding season (Scott and Clarke, 1993b). This suggests that GABA neurones, acting through the $G_{A B A}$ receptor, are actively restraining GnRH secretion in the presence of oestrogen during the non-breeding season. Similarly, GABA actions on $\mathrm{LH}$ release through the $G A B A_{B}$ receptor have been identified only in oestrogen-treated ovariectomized ewes during anoestrus, although, in this instance, the effects appear to be mostly on LH pulse amplitude (Scott and Clarke 1993b). The presence of oestrogen receptors in preoptic GABA neurones (Herbison et al., 1993a) and probably direct GABA innervation of GnRH neurones in ewes (Karsch et al., 1989), combined with evidence for preoptic GABA neurones mediating negative feedback influences of oestrogen on $\mathrm{LH}$ secretion in rats (Herbison et al., 1991), makes the preoptic GABA neurones of ewes a likely target for oestrogen in inhibiting $\mathrm{LH}$ secretion during the non-breeding season. It will be interesting to examine whether preoptic GABA neurones in the ram possess oestrogen receptors or androgen receptors and to determine whether there is an equivalent role for these cells in the negative feedback influences of testosterone on LH secretion.

Although there is little evidence that $\beta$-endorphin neurones mediate oestrogen negative feedback actions on LH secretion during anoestrus (Brooks et al., 1986; Horton et al., 1989), naloxone has been shown by several groups to stimulate LH secretion in the breeding season (Horton et al., 1989: Conover et al., 1993; Goodman, 1994). Whether this tonic inhibition of $\mathrm{GnRH}$ neurones by $\beta$-endorphin is brought about by steroid dependent or independent mechanisms is not fully understood but recent 
evidence indicates that $\beta$-endorphin concentrations in the median eminence increase from luteal to follicular stages of the oestrous cycle before falling at the time of the LH surge (Domanski et al., 1991; Conover et al., 1993). This pattern of increasing $\beta$-endorphin concentrations coincides with increasing oestrogen concentrations and the presence of oestrogen receptors in $\beta$-endorphin cells (Lehman and Karsch, 1993) makes it possible that oestrogen stimulates these cells directly. Although oestrogen is not known to have dominant negative feedback effects during the sheep oestrous cycle (Goodman, 1994), Evans et al. (1993) reported that oestradiol acts centrally to reduce GnRH pulse size immediately before the LH surge, an action compatible with an oestrogen-induced increase in opioid tone at the level of the median eminence (Conover et al, 1993). As $\beta$-endorphin is likely to influence GnRH neurones at both their cell bodies and terminals, it may play a particularly important role in preventing the premature activation of GnRH neurones early in the follicular phase (Domanski et al., 1991; Conover et al., 1993). Rams have also been shown to have an endogenous opioid mechanism restraining $\mathrm{LH}$ secretion which, as in ewes, is active only in the breeding season and in the presence of gonadal steroids (Lincoln et al., 1987). Whether $\beta$-endorphin cells in the ARN of the male possess oestrogen receptors or androgen receptors is not known but, on the basis of the similar steroid-dependent actions of opioids on $\mathrm{LH}$ secretion in males and females, it is possible that there is a similar pattern of gonadal steroid receptor localization within $\beta$-endorphin cells in rams.

Finally, it is interesting to speculate on the possible role(s) of the steroid-receptive somatostatin neurones located in the ventrolateral division of the VMN. Blache et al. (1991) showed that implants of oestrogen in the general region of the VMN induce sexual behaviour as well as increments in LH secretion in steroid-treated ewes during the breeding season, and Moenter et al. (1993) reported increased immediate early gene expression in cells of the ventrolateral VMN following the oestrogeninduced LH surge. Such findings suggest that oestrogen-receptive neurones in the VMN may participate in the positive feedback effects of oestrogen on both reproductive behaviour and LH secretion. Hence, the cells synthesizing somatostatin in the VMN, which account for nearly three-quarters of the oestrogen-receptor-expressing neurones in this region in ewes, might be considered to play a role in one or both of these functions. Although somatostatin is known to be a potent inhibitory neurotransmitter in the rat hypothalamus (Renaud et al, 1975), little is known about the function of VMN somatostatin neurones in any species. Somatostatin neurones in the ventrolateral VMN of the female rat also possess oestrogen receptors and preliminary evidence suggests that many of these somatostatin cells are activated during mating (Herbison, 1994). A similar situation may occur in sheep as, unless there is a marked sex difference in the role of somatostatin neurones in the VMN, the observation that they possess oestrogen receptors in ewes and androgen receptors in rams suggests that these cells may be more involved in modulating sexual behaviour than the $\mathrm{LH}$ surge. However, it should be noted that neurones containing oestrogen receptors in the VMN of rats project to the POA and interconnections between these two steroid-receptive areas are well described in rats (Morrell et al., 1992) and sheep (Tillet et al., 1993). Hence, an identified steroid-receptive neural population in the POA or VMN may function in the steroid-dependent actions of both regions.

\section{Conclusions}

Considerable progress has been made in defining the sites of oestrogen and androgen action in the sheep hypothalamus and a rational hypothesis can be formulated for the ways in which these steroids influence $\mathrm{GnRH}$ neurones in the breeding and non-breeding seasons. However, much remains to be done at both neuroanatomical and whole animal levels. In particular, the need for a full description of cells expressing oestrogen receptors in the ram hypothalamus and both qualitative and quantitative descriptions of neurones containing oestrogen receptors and androgen receptors in males and females, and in both seasons of the year are required. The identification of female-predominant sex differences in gonadal-steroid-receptive neurones may provide important information regarding the specific neural populations responsible for the generation of the LH surge in ewes. So far, we have identified only inhibitory neurotransmitters or neuropeptides in steroid-receptive cells of the sheep hypothalamus. It is envisaged that the combination of steroid receptor and immediate early gene immunocytochemistry, 
with or without the addition of neuroanatomical tracing methodologies, will be of great use in defining precisely which neurochemically identified, steroid-receptive neurones are involved in regulating which steroid-regulated components of reproductive behaviour and hormone secretion.

R. J. Bicknell and J. E. Robinson are thanked for critical reading of an earlier version of this manuscript as are D. Skinner and T. Harris for invaluable assistance in the sheep perfusions. G. Prins and Abbott Laboratories (Chicago) are thanked for the generous gifts of androgen and oestrogen receptor antibodies, A. E. Herbison is a Lister Institute-Jenner Fellow.

\section{References}

Batailler M, Blache D, Thibault J and Tillet $Y$ (1992) Immunohistochemical colocalization of tyrosine hydroxylase and estradiol receptors in the sheep arcuate nucleus Neuroscience Letters $146 \quad 125-130$

Bittman EL and Blaustein JD (1990) Effects of day length on sheep neuroendocrine oestrogen and progestin receptors American Joumal of Physiology 258 R135-142

Blache D, Fabre-Nys CJ and Venier G (1991) Ventromedial hypothalamus as a target for oestradiol action on proceptivity, receptivity and luteinizing hormone surge of the ewe Brain Research 546 241-249

Blache D, Batailler M and Fabre-Nys C (1994) Oestrogen receptors in the preoptic-hypothalamic continuum: immunohistochemical study of the distribution and cell density during induced oestrous cycle in ovariectomized ewe Joumal of Neurocndocrinolog!y 6 329-339

Blaustein JD (1993) Estrogen receptor immunoreactivity in rat brain: rapid effect of estradiol injection Endocrinology 132 1218-1224

Blaustein JD and Turcotte IC (1989) Estrogen receptorimmunostaining of neuronal cytoplasmic processes as well as cell nuclei in guinea pig brain Brair Rescarch 495 $75-82$

Bloch GJ, Kurth SM, Akesson TR and Micevych PE (1992) Estrogen-concentrating cells within cell groups of the medial preoptic area: sex differences and co-localization with galanin-immunoreactive cells Brain Research 595 301-308

Brooks AN, Haynes NB, Yang $K$ and Lamming GE (1986) Ovarian steroid involvement in endogenous opioid modulation of LH secretion in seasonally anoestrous mature ewes Joumal of Reproduction and Ferfilify $76709-715$

Caraty A and Locatelli A (1988) Effect of time after castration on secretion of GnRH and $\mathrm{LH}$ in the ram Joumal of Reproduction and Fertility 82 263-269

Cintra A, Fuxe K, Härfstrand A, Agnati LF, Miller LS, Greene JL. and Gustafsson IA (1986) On the cellular localization and distribution of oestrogen receptors in the rat tel- and diencephalon using monodonal antibodies to human oestrogen receptor Neurochemistry International 8 587-595

Clarke IJ, Burman JW, Funder JW and Findlay JK (1981) Estrogen receptors in the neuroendocrine fissues of the ewe in relation to breed, season, and stage of the estrous cycle Biology of Reproduction 24 323-331

Conover CD, Kuljis RO, Rabit J and Advis J-P (1993) Beta-endorphin regulation of luteinizing hormone-releasing hormone release at the median eminence in ewes: immunocytochemical and physiological evidence Neuroendocrinology 57 1182-1195
D’Occhío MJ, Schanbacher BD and Kinder JE (1983) Androgenic and oestrogenic steroid participation in feedback control of luteinizing hormone secretion in male sheep Acta Endocrinologica 102 499-504

Domanski E. Chomicka LK, Ostrowska A. Gajewska A and Mateusiak K (1991) Release of luteinizing hormonereleasing hormone, beta-endorphin and noradrenaline by the nucleus infundibularis/median eminence during preovulatory period in the sheep Neuroendocrinology 54 151-158

Evans NP, Dahl GE, Glover BH and Karsch FJ (1994) Central regulation of pulsatile gonadotropin-releasing hormone $(\mathrm{G} n \mathrm{RH})$ secretion by estradiol during the period leading up to the preovulatory GnRH surge in the ewe Endocrinology $1341800-1812$

Flugge G, Oertel WH and Wuttke W (1986) Evidence for oestrogen-receptive GABAergic neurons in the preoptid anterior hypothalamic area of the rat brain Neurvendocrinology 43 1-5

Geffroy-Roisne S, Madigou T, Pelletier J and Thieulant M-L (1993) Size heterogeneity of affinity-labeled oestrogen receptor in the ram hypothalamo-pituitary axis Neuroendocrinology $\mathbf{5 7} 648-653$

Glass JD. Amann RP and Nett TM (1984) Effects of season and sex on the distribution of cytosolic oestrogen receptors within the brain and the anterior pituitary gland of sheep Biology of Reproduction $30894-902$

Goodman RL. (1994) Neuroendocrine control of the ovine estrous cycle, In The Physiology of Reproduction Vol. 2 pp 659-710 Ed. E Knobil and ID Neill. Raven Press, New York

Greene GL, Sobel NB, King W] and Jensen EV (1984) Immunochemical studies of oestrogen receptors Joumal of Steroid Biochemistry $2051-50$

Havern RL. Whisnant CS and Goodman RL. (1994) Dopaminergic structures in the ovine hypothalamus mediating estradiol negative feedback in anestrous ewes Endocrinology 134 1905-1911

Herbison AE (1994) Somatostatin-immunoreactive neurones in the hypothalamic ventromedial nucleus possess oestrogen receptors in the male and female rat Joumal of Neuroendocrinology 6 323-328

Herbison AE and Theodosis DT (1992a) Localization of oestrogen receptors in preoptic neurons containing neurotensin but not tyrosine hydroxylase, cholecystokinin or luteinizing hormone-releasing hormone in the male and female rat Neurositence $50 \quad 283-298$

Herbison AE and Theodosis DT (1992b) Immunocytochemical identification of oestrogen receptors in preoptic neurones containing calcitonin gene-related peptide in the male and female rat Neuroendocrinology $56761-764$ 
Herbison AE and Theodosis DT (1993) Absence of oestrogen receptor immunoreactivity in somatostatin (SRIF) neurons of the periventricular nucleus but sexually dimorphic colocalization of oestrogen receptor and SRIF immunoreactivities in neurons of the bed nucleus of the stria terminalis Endocrinology 132 1707-1713

Herbison AE, Heavens RP, Dye S and Dyer RG (1991) Acute action of oestrogen on medial preoptic gammaaminobutyric acid neurons: correlation with oestrogen negative feedback on luteinizing hormone secretion Joumal of Neuroendocrinology 3 I0I-106

Herbison AE, Augood SJ and McGowan EM (1992) Expression of glutamic acid decarboxylase messenger RNA in rat medial preoptic area neurons during the oestrous cycle and after ovariectomy Molecular Brain Research 14 310-316

Herbison AE, Robinson JE and Skinner DC (1993a) Distribution of oestrogen receptor-immunoreactive cells in the preoptic area of the ewe; co-localization with glutamic acid decarboxylase but not luteinizing hormone-releasing hormone Neuroendocrinology $57751-759$

Herbison AE, Robinson JE and Skinner DC (I993b) Calcitonin gene-related peptide (CGRP): immunocytochemical identification of a neuropeptide synthesised by ventral paraventricular magnocellular neurones in the sheep Brain Research 611 147-151

Herbison AE, Horvath TL, Naftolin F and Leranth C Distribution of oestrogen receptor-immunoreactive cells in monkey hypothalamus: relationship to neurones containing luteinizing hormone-releasing hormone and tryrosine hydroxylase Neuroendocrinology (in press)

Horton RJE, Francis H and Clarke IJ (1989) Seasonal and steroiddependent effects on the modulation of LH secretion in the ewe by intracerebroventricularly administered $\beta$-endorphin or naloxone Jourval of Endocrinology 122 509-517

Huang X and Harlan RE (1993) Absence of androgen receptors in GnRH immunoreactive neurons Brain Reseurch 624 309-311

Jirikowski GF, Merchenthaler I, Rieger GE and Stumpf WE (1986) Estradiol target sites immunoreactive for $\beta$-endorphin in the arcuate nucleus of the rat and mouse hypothalamus Neuroscience Letters $65121-126$

Ju G and Swanson LW (1989) Studies on the cellular architecture of the bed nuclei of the stria terminalis in the rat: I. Cytoarchitecture Jourtal of Comparative Neurology 280 $587-602$

Karsch FJ, Ebling FJP and Lehman MN (1989) Do catecholaminergic, neuropeptide $Y$, substance $P$ and GABAergic terminals innervate GnRH neurons in the sheep? Socitty for Neuroscience Abstracts $\mathbf{1 5} 1083$

Koch M and Ehret G (1989) Immunocytochemical localization and quantitation of oestrogen-binding cells in the male and female (virgin, pregnant, lactating) mouse brain Brain Research 489 101-112

Kuljis RO and Advis IP (1989) Immunocytochemical and physiological evidence of a synapse between dopamine- and luteinizing hormone releasing hormone-containing neurons in the ewe median eminence Endocrinology 124 1579-1583

Lehman MN and Karsch FJ (1993) Do gonadotropin-releasing hormone, tyrosine hydroxylase- and $\beta$-endorphinimmunoreactive neurons contain oestrogen receptors? A double-label immunocytochemical study in the Suffolk ewe Endocrinology 133 887-895

Lehman MN, Ebling FJP, Moenter SM and Karsch FJ (1993) Distribution of oestrogen receptor-immunoreactive cells in the sheep brain Endocrinology 133 876-886
Lincoln GA, Ebling FIP and Martin GB (1987) Endogenous opioid control of pulsatile LH secretion in ram5! modulation by photoperiod and gonadal steroids Journal of Endocrinology $115 \quad 425-438$

Menard CS and Harlan RE (1993) Up-regulation of androgen receptor immunoreactivity in the rat brain by androgenicanabolic steroids Brain Research 622 226-230

Moenter SM, Karsch FJ and Lehman MN (1993) Fos expression during the estradiol-induced gonadotropin-releasing hormone $(\mathrm{GnRH})$ surge of the ewe induction in $\mathrm{GnRH}$ and other neurones Endocrinology 133 896-903

Morrell JI, McGinty JF and Pfaff DW (1985) A subset of beta-endorphin or dynorphin-containing neurons in the medial basal hypothalamus accumulates estradiol Neuro. endocrinology $41417-426$

Morrell JI, Corodimas KP, DonCarlos LL and Lisciotto CA (1992) Axonal projections of gonadal steroid receptor-containing neurons Neuroprotocols 1 4-15

Pelletier J and Ortavant R (1975) Photoperiodic control of LH release in the ram II. Light-androgens interaction Acla Endocrinologici 78 442-450

Prins GS, Birch L and Greene GL (1991) Androgen receptor localization in different cell types of the adult rat prostate Endocrinology 129 3187-3199

Renaud LP, Martin JB and Brazeau P (1975) Depressant action of TRH, LH-RH and somatostatin on the activity of central neurones Nature 255 233-235

Robinson JE and Kendrick KM (1992) Inhibition of luteinizing hormone secretion in the ewe by progesterone: associated changes in the release of gamma-aminobutyric acid and noradrenaline in the preoptic area as measured by intracranial microdialysis Joumal of Neuroendocrinology 4 231230

Robinson JE, Kendrick KM and Lambart CE (1991) Changes in the release of gamma-aminobutyric acid and catecholamines in the preopticlseptal area prior to and during the preovulatory surge of luteinizing hormone in the ewe Joumal of Neuroendocrinology 3 393-399

Sar M (1988) Distribution of progestin-concentrating cells in rat brain: colocalisation of $\left.\mathrm{I}^{3} \mathrm{H}\right] \mathrm{ORG} .2058$, a synthetic progestin, and antibodies to tyrosine hydroxylase in hypothalamus by combined autoradiography and immunocytochemistry Endocrinology $123 \quad 1110-1118$

Scott CI and Clarke IJ (1993a) Inhibition of LH secretion in ovariectomised ewes during the breeding season by $\gamma$-aminobutyric acid (GABA) is effected by GABA-A receptors but not GABA-B receptors Endocinology 132 $1789-1796$

Scott CJ and Clarke IJ (1993b) Evidence that changes in the function of the subtypes of the receptors for $\gamma$-amino butyric acid may be involved in the seasonal changes in the negative-feedback effects of oestrogen on gonadotropinreleasing hormone secretion and plasma luteinizing hormone levels in the ewe Endocrinology 133 2904-2912

Shivers BD, Harlan RE, Morrell 11 and Pfaff DW (1983) Absence of estradiol concentration in cell nuclei of $\mathrm{GnRH}$ immunoreactive neurons Nature 304 345-347

Simerly RB and Young BJ (1991) Regulation of oestrogen receptor messenger ribonucleic acid in rat hypothalamus by sex steroid hormones Molecular Endocrinology 5 424-432.

Skinner DC, Herbison AE and Robinson JE (1992) Immunocytochemical identification of oestrogen receptors in the ovine pars tuberalis: localization within gonadotrophs Jommal of Neuroendoctinology 4 659-602 
Thiery J-C, Martin GB, Tillet Y, Caldani M, Quentin M, Jamain C and Revault J-P (1989) Role of hypothalamic catecholamines in the regulation of luteinizing hormone and prolactin secretion in the ewe during, seasonal anestrus Neuroendocrinology $4980-87$

Thompson TL and Moss RL (1994) Estrogen regulation of dopamine release in the nucleus accumbens: genomic- and nongenomic-mediated effects Journal of Neurochemistry 62 $1750-1750$

Tilbrook AJ and Clarke II (1992) Evidence that dopaminergic neurons are not involved in the negative feedback effect of testosterone on luteinizing hormone in rams in the nonbreeding season Joumal of Neuroendocrinology 4 365-374

Tilbrook AJ, de Kretser DM, Cummins JT and Clarke IJ (I99I) The negative feedback effects of testicular steroids are predominantly at the hypothalamus in the ram Endocrinology 129 3080-3092.
Tillet Y, Batailler M and Thibault J (1993) Neuronal projections to the medial preoptic area of the sheep, with special reference to monoaminergic afferents: immunohistochemical and retrograde tract tracing studies Journal of Comparative Netrology $330195-220$

Watson RE Jr, Langub MC Jr and Landis JW (1992) Further evidence that most luteinizing hormone-releasing hormone neurons are not directly oestrogen-responsive: simultaneous localisation of luteinizing hormone-releasing hormone and oestrogen receptor immunoreactivity in the guinea-pig brain Journal of Neuroendocrinology 4 311-318

Watson RE Jr, Hutchinson RK, Langub MC Jr, Landis JW, Seksaria S, Rainey DM and Keil LC (1994) Colocalization of natriuretic peptide and oestrogen receptor immunoreactivities in preoptic nuclei in the fernale rat Journil of Neuroendocnnology 6 79-87 